\title{
Recycling fine slurry - an alternative to paste for coarse rejects co-disposal in Queensland coal mines
}

\author{
AD Thomas Slurry Systems Pty Ltd, Australia \\ NT Cowper Snr Slurry Systems Pty Ltd, Australia \\ S Whitton Mechanical Advantage Pty Ltd, Australia
}

\begin{abstract}
Conventional co-disposal of coarse rejects (minus $50 \mathrm{~mm}$ ) and fine thickener underflow tailings (minus $2 \mathrm{~mm}$ ) is practised at a number of Queensland coal mines. The two streams are combined and pumped together to disposal. However, with the ratio of coarse rejects to tailings typically being about 70:30 on a dry mass basis, it is necessary to add large quantities of water to reduce the volume concentration of coarse rejects to an acceptable pumpable level. At the disposal site, the low concentration fines wash through the coarse rejects, forming a pond at the toe of the deposit. Water needs to be recovered from the pond and pumped back to the plant, and some water is lost through evaporation. The deposit also requires significant management with earthmoving equipment.
\end{abstract}

An alternative co-disposal system is described, in which no dilution water is required. By recycling some of the minus $2 \mathrm{~mm}$ thickener underflow in a recycle pipeline, the required reduction in volume concentration of rejects in the mixture is achieved without water dilution. With a thickener underflow concentration of 50\% by weight $(w / w)$, the total mixture concentration discharged to disposal is up to $75 \% \mathrm{w} / \mathrm{w}$, and the discharged mixture is essentially homogeneous with minimal separation of fines. The emplacement can take the form of a cone-shaped deposit, thereby greatly reducing the earthworks required. The net effect is that total costs are about half of that required for the current co-disposal systems.

The $75 \% \mathrm{w} / \mathrm{w}$ concentration achieved by recycling fines is similar to the concentration likely to be delivered by proposed laminar flow paste pipeline systems, and is achieved with more reliable turbulent flow operation, avoiding the uncertainties associated with laminar flow.

\section{Introduction}

\subsection{Current operating co-disposal systems}

A coal washery generates two main waste streams: minus $50 \mathrm{~mm}$ coarse rejects and minus $2 \mathrm{~mm}$ thickener underflow tailings. Traditionally, these have been disposed of separately, with the coarse rejects transported to the disposal area by trucking or by conveyor belt and the tailings pumped to a tailings dam. In recent years, two methods for co-disposing of the two streams have been used at some mines.

The first method of co-disposal involves combining the coarse rejects with thickener underflow from a conventional thickener and pumping the mixture to the disposal site. Pumped co-disposal of $50 \times 2 \mathrm{~mm}$ coarse rejects and minus $2 \mathrm{~mm}$ fine tailings thickener underflow is currently practised at a number of Queensland coal mines. Ideally, the two streams can be directly combined and pumped to the disposal site in a co-disposal pipeline. However, in Queensland, a typical mine produces more coarse rejects than fine tailings, with a ratio (dry tonnes basis) in the order of 70:30. If tailings thickener underflow at $40 \% \mathrm{w} / \mathrm{w}$ is combined with the coarse rejects, the volume concentration of rejects in the mixture is generally over $30 \%$, which is far too high for reliable turbulent flow pumping. (Note: all concentrations in this paper are weight concentrations unless specifically identified as volume concentrations). Water must be added to reduce the 
volume concentration of rejects to a maximum $15 \%$ and generally around $7 \%$. As a consequence, the low rheology tailings are not completely trapped in the rejects at the disposal site, but gravitate through the deposit to form an undesirable pond at the toe of the deposit. A significant amount of water is lost through evaporation from the pond, with the balance needing to be recycled by pumping back to the plant.

The second method of co-disposal currently in use at a few mines involves thickening the tailings to high concentration using either a paste thickener or filters, then adding this paste to the coarse rejects before disposing of the combined mixture using either trucks or a conveyor belt to transport the mixture. Consideration has been given to the possibility of pumping the combined paste mixture, but at the time of writing, the authors are not aware of any operating co-disposal paste pumping systems in the coal industry. However, at least one co-disposal laminar flow paste pumping system is believed to be being trialled in loop tests.

\section{$1.2 \quad$ The recycling fine slurry (RFS) system}

The RFS system (Australian Patent No. 749085) overcomes the low concentration problems of existing pumped co-disposal systems by allowing the rejects to be pumped at the maximum thickener underflow concentration within the requirement to maintain turbulent flow in the pipeline. The maximising of the thickener underflow concentration is achieved by recovering and recycling a portion of the minus $2 \mathrm{~mm}$ fine tailings. At the disposal site, the plus $2 \mathrm{~mm}$ material is separated in a fines recovery system consisting of a cyclone mounted over a fines recovery sump. A portion of the cyclone overflow is returned back to the preparation plant in the fines recycle pipeline. The remainder overflows the sump to join the cyclone underflow rejects flowing to disposal. The cyclone separation is not required to be efficient since only about two thirds of the minus $2 \mathrm{~mm}$ material needs to be recovered. The recycling of the minus $2 \mathrm{~mm}$ tailings achieves the required decrease in volume concentration of rejects in the main pipeline without the need to dilute the tailings with water addition. Flow in both pipelines is turbulent avoiding any uncertainty regarding deposition and possible blockages associated with laminar paste flow. With a thickener underflow concentration of $50 \% \mathrm{w} / \mathrm{w}$, the combined mixture concentration deposited at the reject emplacement is around $75 \% \mathrm{w} / \mathrm{w}$.

On a flat disposal site, the higher residual slurry density allows the combined rejects and thickened tailings emplacement to be made as a single cone, negating the need to construct numerous small containment cells and removing most of the manning and earthmoving associated with the management of current co-disposal systems. With an elevated, cone-shaped emplacement, there will generally be sufficient head available for the recycle pipeline to operate by gravity. If discharging into a void, the recycle pipeline will require a pump located at the rim of the void. When discharging into a void, the limited water runoff from the high concentration mixture reduces the high pump head and pumping costs of returning water from the bottom of the void.

It was noted above that loop tests are believed to be being conducted on a pumped laminar flow paste co-disposal system. However, if this concept does prove viable, it is likely to involve higher pump pressures than the RFS system, and may be susceptible to blockages and deliver only marginally higher concentrations to disposal than the RFS system. The authors believe the reliable turbulent flow operation of the RFS system is preferred.

\section{Conventional co-disposal system}

\subsection{General parameters of conventional co-disposal system}

The rheology of the thickener underflow fines will vary between mines. However, the authors have experience with thickener underflow rheology from at least five Queensland mines and for three of these mines the yield stress of the thickener underflow is similar at around $1 \mathrm{~Pa}$ at $40 \% \mathrm{w} / \mathrm{w}$ concentration and around $7 \mathrm{~Pa}$ at $50 \% \mathrm{w} / \mathrm{w}$. The other two mines have a higher rheology thickener underflow. The yield stress 
and plastic viscosity of the thickener underflow fines slurry for the three similar mines is approximated by the following two equations, and this rheology will be used in comparisons in this paper.

$$
\begin{gathered}
\tau y=0.001786 \exp \left(0.164 \mathrm{CW}_{\text {fines }}\right) \\
\mu_{\mathrm{pl}}=\exp \left(4.6737 \mathrm{Vr}_{\text {fines }}\right)
\end{gathered}
$$

Where:

$$
\begin{array}{ll}
\tau_{\mathrm{y}} & =\text { yield stress }(\mathrm{Pa}) . \\
\mu_{\mathrm{pl}} & =\text { plastic viscosity at } 20^{\circ} \mathrm{C} \text { (mPas). } \\
\mathrm{CW}_{\text {fines }} & =\text { solids concentration by weight } \% \text { of the thickener underflow fines slurry } . \\
\mathrm{V}_{\text {fines }} & =\quad \text { volume ratio fines }=\text { volume fine solids/volume of water. }
\end{array}
$$

Consider a conventional co-disposal system to transport 315 tonnes per hour (tph) of coarse, minus $50 \mathrm{~mm}$ rejects at $4.4 \% \mathrm{w} / \mathrm{w}$ moisture and $135 \mathrm{tph}$ of minus $2 \mathrm{~mm}$ of thickener underflow fine tailings at $40 \% \mathrm{w} / \mathrm{w}$ concentration. The solids specific gravity (SG) of the coarse rejects is 2.2 and the fine tailings SG is 1.73 . If the two streams were simply combined, the volume concentration of coarse rejects in the slurry would be $32.7 \%$, which is far too high for reliable turbulent flow pumping of such coarse particles. In the typical conventional co-disposal systems, for reliable operation, the volume concentration of rejects is reduced to about $7.5 \%$ by addition of water. In the present example, if a rejects volume concentration of $7.5 \%$ is assumed, an addition of $1,460 \mathrm{~m}^{3} / \mathrm{h}$ of water is required, giving a rejects concentration of $14.9 \% \mathrm{w} / \mathrm{w}$ and a total solids concentration of $21.2 \% \mathrm{w} / \mathrm{w}$. Typically, two parallel pipelines are installed with the total flow rate of $1,898 \mathrm{~m}^{3} / \mathrm{h}$ split equally between the two pipelines. After the addition of the water, the concentration of the fines in the mixture is reduced to just $7.5 \% \mathrm{w} / \mathrm{w}$. The viscosity of the fines 'vehicle' slurry is only $1.25 \mathrm{mPas}$ and the fines 'vehicle' slurry provides negligible assistance in transporting the coarse rejects, which are essentially pumped in dirty water. When the resultant low concentration slurry is discharged at the disposal site, the fines and the rejects segregate, with the majority of the fines filtering through the rejects to form a fine particle slurry pond at the toe of the deposit. The deposited solids are non-homogeneous. A significant amount of water in the pond is lost through evaporation with the remainder needing to be pumped back to the washery.

\subsection{Pump heads and power requirements for conventional co-disposal systems}

For the throughputs considered above, a DN300 steel pipe is appropriate. A Schedule 80 pipe (wall thickness $17.5 \mathrm{~mm}$ ) gives an ID of $289 \mathrm{~mm}$ and a velocity of $4 \mathrm{~m} / \mathrm{s}$. Towards the end of the pipeline $355 \mathrm{OD}$ PN16 HDPE pipe, with a similar $289 \mathrm{~mm}$ ID, might be used. Two such pipelines are required.

The predicted deposit velocity for this coarse slurry in the DN300 pipe is around $3 \mathrm{~m} / \mathrm{s}$ and the operating velocity of $4 \mathrm{~m} / \mathrm{s}$ provides a suitable safety margin above deposition. The predicted head loss gradient is $75 \mathrm{~m} / \mathrm{km}$ for coarse rejects volume concentration $7.5 \%$. The head loss gradient equates to a pressure gradient of $827 \mathrm{kPa} / \mathrm{km}$. The disposal site is typically about 1-1.3 $\mathrm{km}$ from the plant and the elevation of the disposal site is often 10-20 m above the relative level of the pumps. Two centrifugal gravel pumps in series per pipeline are required. Each application will differ in pipeline length and disposal site elevation. For ease of comparison between conventional and RFS systems, all pump powers are calculated for $1 \mathrm{~km}$ of pipeline with zero elevation difference between the pumps and the disposal site.

Assuming the following pump efficiencies:

- Pump efficiency on water $=0.70$ ( 0.80 for return water pump).

- Energy down-rating factor for coarse particles (ERF) $=0.85$ (1 for return water pump).

- Mechanical drive efficiency $=0.92$.

- Gland seal water efficiency $=0.98$. 
- Electrical drive efficiency $=0.95$.

- Total efficiency $=0.51$ (0.69 for return water pump).

The predicted pressure gradient at $4 \mathrm{~m} / \mathrm{s}$ in a 289 ID pipe is $827 \mathrm{kPa} / \mathrm{km}$ giving an operating electrical power per pipeline $=425 \mathrm{~kW}$ and total operating electrical power for two pipelines $=850 \mathrm{~kW}$.

At the disposal site, some of the water remains within the deposit, some is lost through evaporation from the toe pond and some is pumped back to the plant. Assuming $50 \%$ of the water is recovered and returned to the plant, the return water flow rate is $840 \mathrm{~m}^{3} / \mathrm{h}$. Assuming a 450 OD HDPE pipe (ID $396 \mathrm{~mm}$ ) is being used, the velocity is $1.89 \mathrm{~m} / \mathrm{s}$ and pressure gradient $57.2 \mathrm{kPa} / \mathrm{km}$, giving an operating electrical power of $20 \mathrm{~kW}$ for water return. Hence, the total operating electrical power per km pumping distance for the conventional co-disposal system is $870 \mathrm{~kW}$.

\section{RFS system}

\subsection{General description}

A typical RFS system schematic is illustrated in Figure 1. It consists of a feed sump, mainline pump(s), a main co-disposal pipeline, a fines recovery cyclone with a cyclone overflow safety screen and fines recovery sump at the disposal site, a recycle pump, and a fines recycle pipeline.

Minus $2 \mathrm{~mm}$ tailings at maximum thickener underflow concentration is pumped from the tailings thickener to the feed sump to join de-watered, minus $50 \mathrm{~mm}$ coarse rejects entering the hopper via a belt feeder. Also discharging into the feed sump is recycled minus $2 \mathrm{~mm}$ slurry returned from the disposal site. The thickener underflow concentration is maintained as high as possible within the requirement to maintain turbulent flow in the co-disposal and recycle pipelines.

At the disposal site, the co-disposal rejects plus recycled fines slurry feeds into a dewatering type cyclone. The cyclone overflow discharges over a $2 \mathrm{~mm}$ screen mounted over a recycle fines recovery sump. The minus $2 \mathrm{~mm}$ fines are recycled back to the collection feed sump at the washery. In the case of a cone-shaped emplacement, the recycle pipeline has the potential to be operated by gravity. In other cases, such as if discharging into a void, a recycle pump will be required. The flow rate in the main pipeline is measured by a magnetic flow meter and controlled by pump speed control to a safe $4 \mathrm{~m} / \mathrm{s}$. The flow rate of minus $2 \mathrm{~mm}$ fines in the fines recycle pipeline is controlled by a pinch valve back at the washery, which maintains a constant level in the main collection hopper. With the flow rate in the recycle pipeline thus controlled, any excess cyclone overflow slurry simply overflows the fines recovery sump to join the cyclone underflow coarse rejects to disposal. 


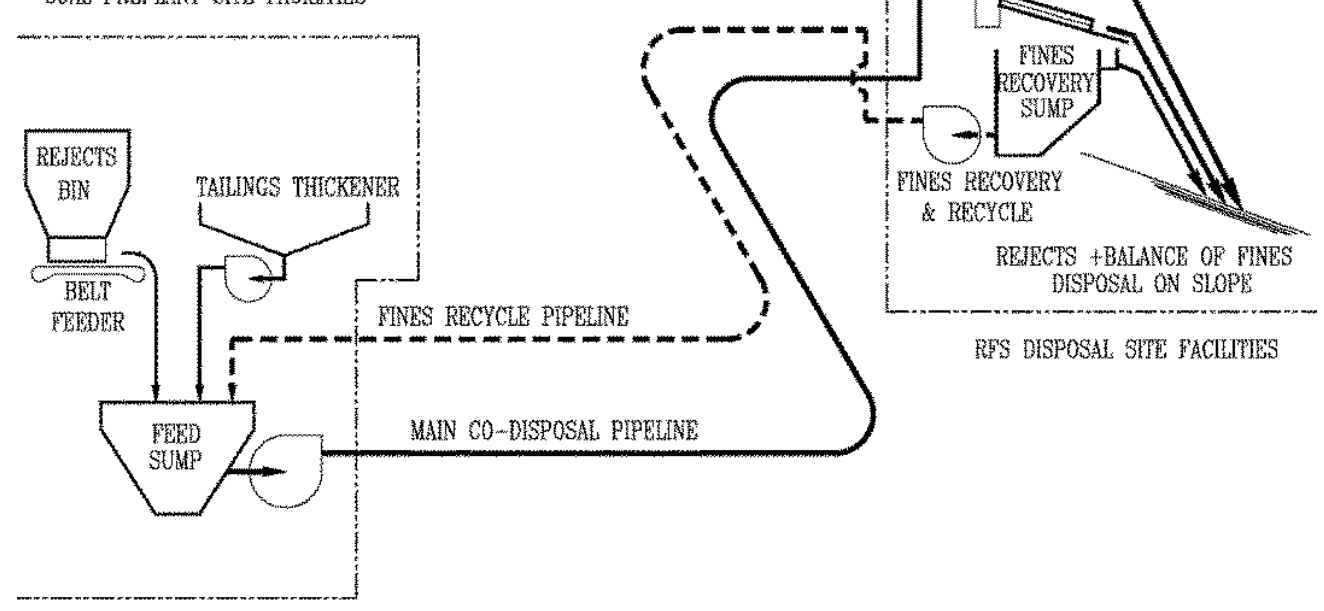

TYPICAL RFS SYSTEM SCHEMATIC

\section{Figure 1 Schematic of typical RFS system}

The general arrangement of the fines recovery and co-disposal unit is shown in Figure 2.

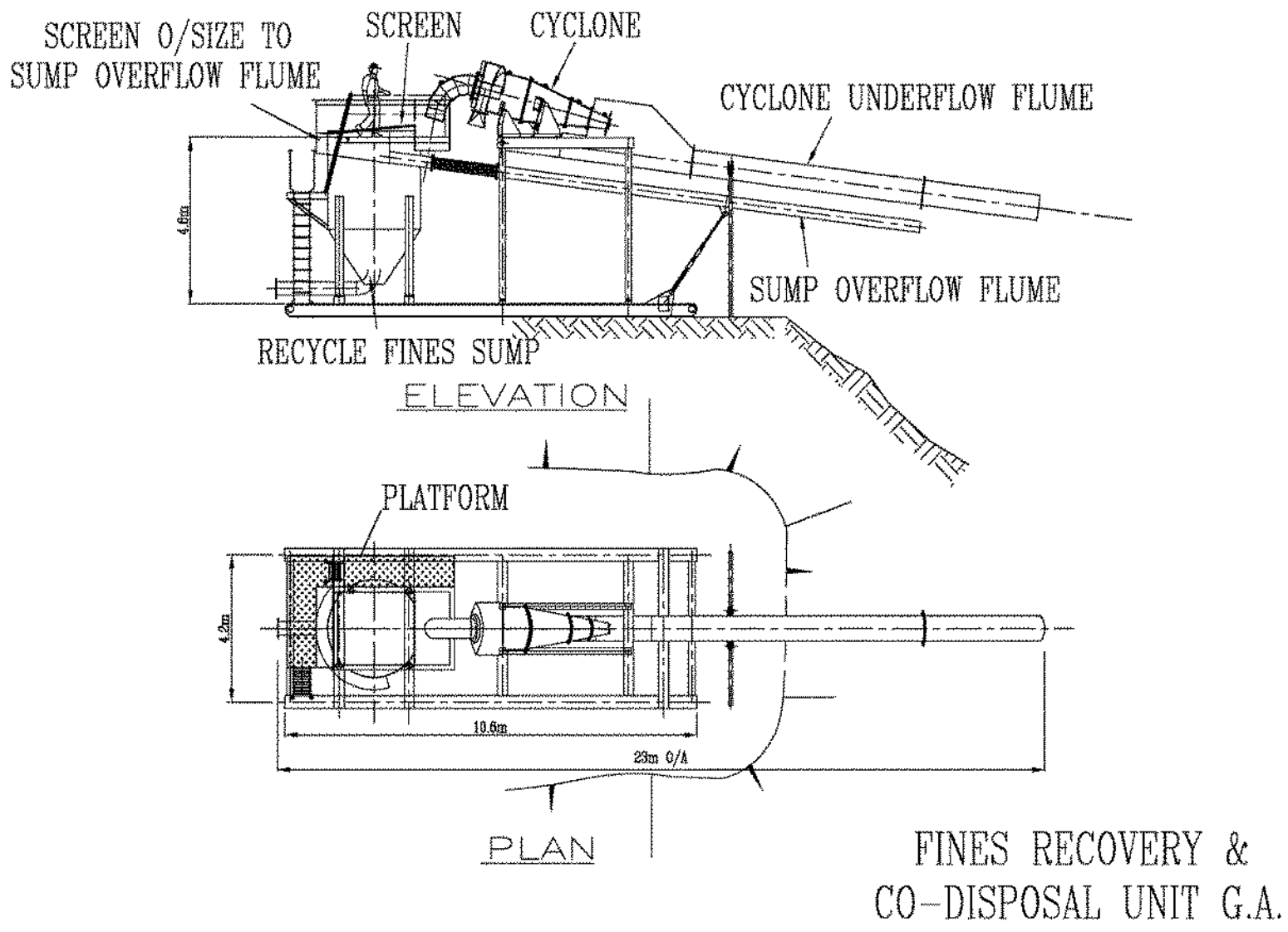

Figure 2 Typical fines recovery and co-disposal general arrangement

\subsection{RFS system - volume concentration of rejects}

It was noted in Section 2 that in the conventional co-disposal system, the volume concentration of coarse rejects is reduced to around $7.5 \%$ by addition of water. The coarse rejects are essentially pumped in dirty 
water with the fines in the water offering no additional support to the coarse rejects. This low volume concentration of coarse rejects is required to provide reliable operation.

In the RFS system, the coarse rejects are combined with the fines at full thickener underflow volume concentration, typically in the range $40-50 \% \mathrm{w} / \mathrm{w}$. The increased density and viscosity of the fines slurry provide additional support to the coarse rejects, allowing a higher concentration of rejects. It is considered that a volume concentration of coarse rejects in the fines slurry of around $15 \%$ will still provide reliable operation.

The increase in volume concentration to $15 \%$ is supported by the results of Paterson and Watson (1979). In pilot plant trials, they report volume concentrations between 8 and $12 \%$ when pumping minus $75 \mathrm{~mm}$ rejects in water. If a volume concentration of $12 \%$ is achievable with minus $75 \mathrm{~mm}$ coarse rejects in water, it is reasonable to assume that a volume concentration of $15 \%$ will provide reliable operation for minus $50 \mathrm{~mm}$ rejects in a $40-50 \% \mathrm{w} / \mathrm{w}$ fines slurry. Experience with coarse coal pumping is also relevant. Prettlin and Gaessler (1976) describe full-scale pumping trials of minus $60 \mathrm{~mm}$ coal in water at volume concentrations up to $14.7 \%$. Siebert et al. (1980) report on three years' operational experience at the Hansa hydraulic mine in Germany, where minus $60 \mathrm{~mm}$ run-of-mine (ROM) coal was pumped at volume concentrations up to $14.3 \%$. Miura and Mase (1979) report on 15 years' operational experience at the Sunagawa hydraulic mine in Japan, where minus $30 \mathrm{~mm}$ ROM coal was pumped at $25 \%$ volume concentration.

The volume concentration of rejects in the RFS main pipeline is directly related to the flow rate (velocity) in the pipeline. Increasing the flow rate from the selected $944-1,020 \mathrm{~m}^{3} / \mathrm{h}$ decreases the rejects volume concentration to $14 \%$, and a flow rate increase to $1,100 \mathrm{~m}^{3} / \mathrm{h}$ decreases the rejects volume concentration to $13 \%$. Thus, a Factor of Safety on pump power will allow the rejects volume concentration to be lowered if required.

\subsection{RFS control philosophy}

The control philosophy of the RFS system is indicated in the RFS flow diagram, Figure 3, discussed in Section 4. The flow rate in the main pipeline is maintained constant by pump speed control based on a magnetic flow meter. The constant flow rate achieves a steady $4 \mathrm{~m} / \mathrm{s}$ velocity. The flow rate in the recycle pipeline is controlled by the pinch valve at the plant so as to maintain a constant level in the feed sump. If the pinch valve closes slightly to maintain the feed sump level constant the flow rate in the recycle pipeline decreases and more minus $2 \mathrm{~mm}$ fines overflow the recovery unit sump to join the rejects to disposal.

\section{RFS system for thickener underflow concentration $40 \% \mathrm{w} / \mathrm{w}$}

\subsection{RFS flow diagram with thickener underflow at $40 \% \mathrm{w} / \mathrm{w}$ concentration}

Figure 3 shows the RFS flow diagram for solids throughputs the same as considered for the conventional co-disposal system in Section 2, i.e. 315 tph (dry basis) of coarse rejects at $4.4 \%$ moisture and 135 tph fines at $40 \% \mathrm{w} / \mathrm{w}$ thickener underflow concentration. The recycle flow rate is selected so as to give a volume concentration of coarse rejects in the main pipeline of $15.2 \%$. The main pipeline consists of DN300 Schedule 80 steel pipe (ID $289 \mathrm{~mm}$ ) followed by 355 OD PN16 HDPE pipe (ID $289 \mathrm{~mm}$ ). The recycle pipeline consists of 355 OD PN10 pipe (ID $312 \mathrm{~mm}$ ).

Unlike the conventional co-disposal system, no dilution water is added. In Figure 3, the thickener underflow concentration is assumed $40 \% \mathrm{w} / \mathrm{w}$. The small amount of water present with the coarse rejects reduces the fines concentration to $38.4 \% \mathrm{w} / \mathrm{w}$. This compares with the $7.5 \% \mathrm{w} / \mathrm{w}$ fines concentration after water dilution with the conventional system described in Section 3.

The recycle pipeline transports $505.8 \mathrm{~m}^{3} / \mathrm{h}$ of minus $2 \mathrm{~mm}$ fines back to the plant in a 355 OD PN10 HDPE pipe, ID $312 \mathrm{~mm}$. The velocity in the recycle pipeline is $1.84 \mathrm{~m} / \mathrm{s}$. 
Figure 3 indicates the total concentration of the slurry discharged at the deposit is $67.5 \% \mathrm{w} / \mathrm{w}$. The $67.5 \%$ total concentration compares with the $21.2 \% \mathrm{w} / \mathrm{w}$ total concentration delivered to the deposit with the conventional co-disposal system described in Section 2 . The total solids concentration pumped in the main pipeline is $53.6 \% \mathrm{w} / \mathrm{w}$, and the volume concentration of coarse rejects in the mixture is $15.2 \%$. The flow rate in the main pipeline is controlled to a constant $944 \mathrm{~m}^{3} / \mathrm{h}$ to give a suitable velocity of $4 \mathrm{~m} / \mathrm{s}$.

The flow rate of minus $2 \mathrm{~mm}$ fines in the main pipeline slurry mixture is $800.8 \mathrm{~m}^{3} / \mathrm{h}$. To maintain the required balanced flow in the recycle pipeline, $505.8 \mathrm{~m}^{3} / \mathrm{h}$, or approximately two thirds of the minus $2 \mathrm{~mm}$ fines, must be separated from the total delivered mixture at the disposal site by the fines recovery unit. It is assumed that the fines recovery unit will separate more than the required $505.8 \mathrm{~m}^{3} / \mathrm{h}$, with the excess simply overflowing from the fines recovery sump. With 231.4 tph of fines at $38.4 \% \mathrm{w} / \mathrm{w}$ concentration returned in the recycle pipeline, there is 135 tph of fines solids and 315 tph of coarse rejects solids delivered to disposal, the same quantities as enter the system.

\section{RFS CO-DISPOSAL SYSTEM}

Legend

\begin{tabular}{|c|c|c|}
\hline \begin{tabular}{|l} 
Fines \\
(tph)
\end{tabular} & $\begin{array}{l}\text { Rejects } \\
\text { (tph) }\end{array}$ & $\begin{array}{l}\text { Water } \\
\text { (tph) }\end{array}$ \\
\hline Fines & Rejects & Total \\
\hline Conc. & Conc. & Conc. \\
\hline Total & Volume & Fines \\
\hline Flow & Conc. & Flow \\
\hline cu. $\mathrm{m} / \mathrm{h}$ & Rejects & cu. $\mathrm{m} / \mathrm{h}$ \\
\hline Fines & Total & \\
\hline Slurry & Slurry & Velocity \\
\hline Density & Densit & $(\mathrm{m} / \mathrm{s})$ \\
\hline
\end{tabular}

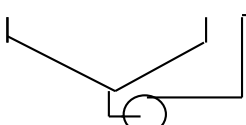

Thickener

\section{FLOW DIAGRAM}

THICKENER UNDERFLOW CONC. $=\mathbf{4 0 . 0}$

315.0 TPH REJECTS 135.0 TPH FINES
FINES SG $=\quad 2.20$

Main pipe diam (mm) 289.0

Return pipe diam $(\mathrm{mm}) \mathbf{3 1 2 . 0}$

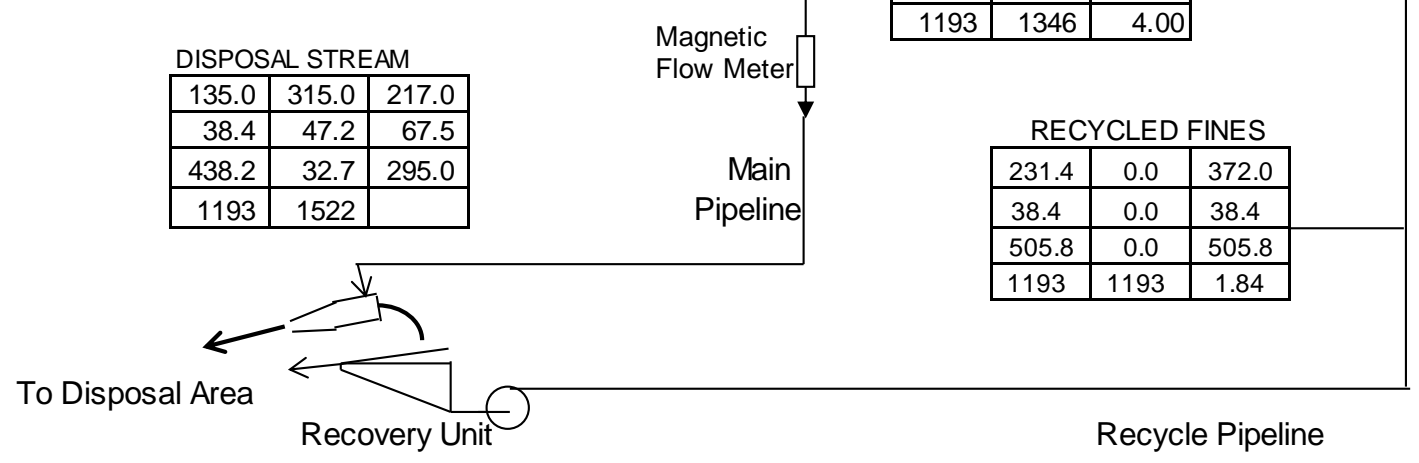

Figure 3 RFS flow diagram for thickener underflow at $40 \%$ w/w concentration

\subsection{Hydraulic issues - thickener underflow concentration $40 \% \mathrm{w} / \mathrm{w}$}

Wilson and Thomas (2006) derived the following equation for the laminar-turbulent transition velocity, Vt, of a Bingham plastic slurry.

$$
\mathrm{Vt}=25\left(\tau_{\mathrm{y}} / \rho\right)^{0.5}
$$

Based on the assumed rheology, the yield stress $\left(\tau_{\mathrm{y}}\right)$ of the fines at $38.4 \% \mathrm{w} / \mathrm{w}$ concentration is $0.97 \mathrm{~Pa}$ and for a slurry density $\left(\rho=1,193 \mathrm{~kg} / \mathrm{m}^{3}\right)$ Equation 3 gives a transition velocity of $0.71 \mathrm{~m} / \mathrm{s}$, well below the 
$1.84 \mathrm{~m} / \mathrm{s}$ velocity in the recycle pipeline and the $4 \mathrm{~m} / \mathrm{s}$ in the main pipeline. Hence, flow in both pipelines is turbulent as required.

\subsection{Pump power requirements - thickener underflow concentration $40 \% \mathrm{w} / \mathrm{w}$}

The predicted pressure gradient in the main pipeline is $1,123 \mathrm{kPa} / \mathrm{km}$ and in the recycle pipeline $112 \mathrm{kPa} / \mathrm{km}$. The respective electrical operating powers are 577 and $23 \mathrm{~kW}$ giving a total operating electrical power per $\mathrm{km}$ of $600 \mathrm{~kW}$. This compares with the $870 \mathrm{~kW}$ required for the conventional system described in Section 2.

Note that the RFS system involves only one main pipeline and one recycle pipeline whereas the conventional co-disposal system transporting the same throughput involves two main pipelines and one return water pipeline.

\section{$5 \quad$ RFS system for thickener underflow concentration $50 \% \mathrm{w} / \mathrm{w}$}

\subsection{RFS flow diagram with thickener underflow at $50 \% \mathrm{w} / \mathrm{w}$ concentration}

If the tailings thickener underflow concentration is increased to $50 \% \mathrm{w} / \mathrm{w}$, the total concentration discharged at the deposit increases to $75.1 \% \mathrm{w} / \mathrm{w}$ as seen in Figure 4.

RFS CO-DISPOSAL SYSTEM

Legend

\begin{tabular}{|c|c|c|}
\hline $\begin{array}{l}\text { Fines } \\
\text { (tph) }\end{array}$ & \begin{tabular}{|l|}
$\begin{array}{l}\text { Rejects } \\
\text { (tph) }\end{array}$ \\
\end{tabular} & $\begin{array}{l}\text { Water } \\
\text { (tph) }\end{array}$ \\
\hline Fines & Rejects & Total \\
\hline Conc. & Conc. & Conc. \\
\hline Total & Volume & Fines \\
\hline $\begin{array}{l}\text { Flow } \\
\text { cu.m/h }\end{array} \mid$ & \begin{tabular}{l|} 
Conc. \\
Rejects
\end{tabular} & $\begin{array}{l}\text { Flow } \\
\text { cu.m/h }\end{array}$ \\
\hline Fines & Total & \\
\hline Slurry & Slurry & Velocity \\
\hline Density & Density & $(\mathrm{m} / \mathrm{s})$ \\
\hline
\end{tabular}

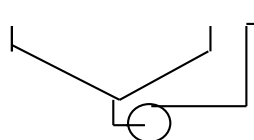

Thickener
FLOW DIAGRAM

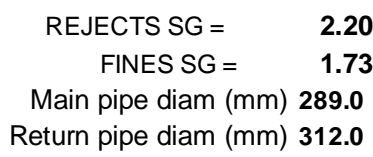

FINES

\begin{tabular}{|r|r|r|}
\hline 135.0 & 0.0 & 135.0 \\
\hline 50.0 & 0.0 & 50.0 \\
\hline 213.0 & 0.0 & 213.0 \\
\hline 1267 & 1267 & \\
\hline
\end{tabular}

DISPOSAL STREAM

\begin{tabular}{|r|r|r|}
\hline 135.0 & 315.0 & 149.5 \\
\hline 47.5 & 52.5 & 75.1 \\
\hline 370.7 & 38.6 & 227.5 \\
\hline 1250 & 1617 & \\
\hline
\end{tabular}

To Disposal Area
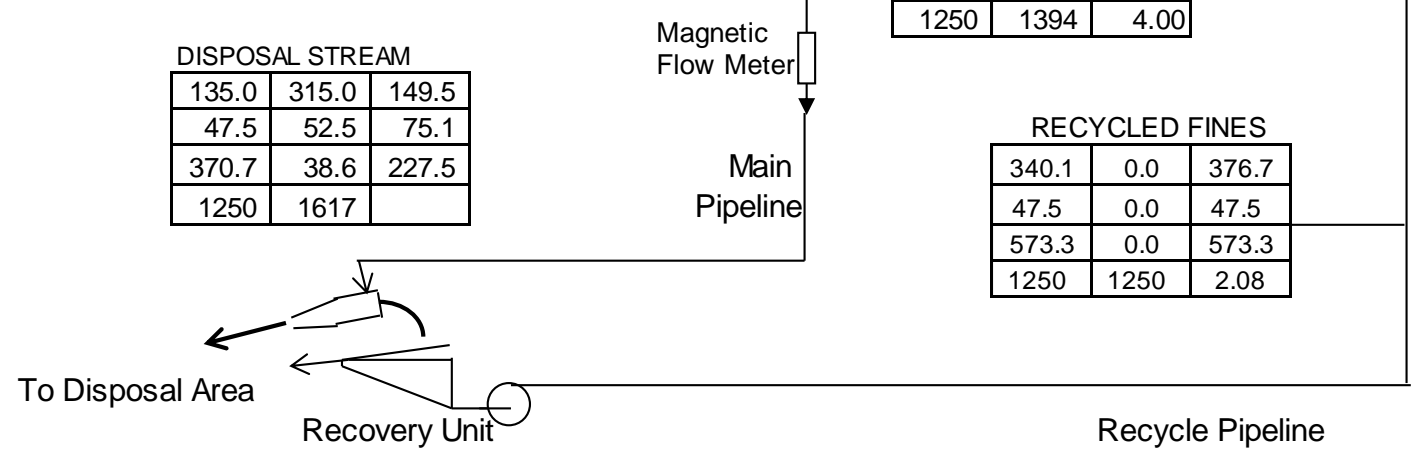

THICKENER UNDERFLOW CONC. $=\mathbf{5 0 . 0}$

315.0 TPH REJECTS 135.0 TPH FINES

Figure 4 RFS flow diagram for thickener underflow at $50 \% \mathrm{w} / \mathrm{w}$ concentration

To maintain the volume concentration of coarse rejects in the main co-disposal pipeline at the desired $15.2 \%$ with the thickener underflow concentration increased to $50 \% \mathrm{w} / \mathrm{w}$, the flow rate in the recycle pipeline is required to increase to $573.3 \mathrm{~m}^{3} / \mathrm{h}$ (c.f. $505.8 \mathrm{~m}^{3} / \mathrm{h}$, applying at $40 \% \mathrm{w} / \mathrm{w}$ thickener underflow 
concentration). As previously mentioned, the flow rate in the main pipeline is controlled to a constant $944 \mathrm{~m}^{3} / \mathrm{h}$ to give a suitable velocity of $4 \mathrm{~m} / \mathrm{s}$.

The flow rate of minus $2 \mathrm{~mm}$ fines in the main co-disposal pipeline slurry mixture is $800.8 \mathrm{~m}^{3} / \mathrm{h}$. To maintain the required balanced flow in the recycle pipeline, $573.3 \mathrm{~m}^{3} / \mathrm{h}$, or approximately $70 \%$ of the minus $2 \mathrm{~mm}$ fines must be separated from the total delivered mixture by the cyclone. It is assumed that the cyclone will separate more than the required $573.3 \mathrm{~m}^{3} / \mathrm{h}$, with the excess simply overflowing from the fines recovery sump. With $340.1 \mathrm{tph}$ of fines at $47.5 \% \mathrm{w} / \mathrm{w}$ concentration returned in the recycle pipeline, there is 135 tph of fines solids and 315 tph of coarse rejects solids delivered to disposal, the same quantities as enter the system.

With a thickener underflow concentration of $50 \% \mathrm{w} / \mathrm{w}$, the RFS system delivers an attractive $75.1 \% \mathrm{w} / \mathrm{w}$ total concentration to disposal. However, achieving $50 \% \mathrm{w} / \mathrm{w}$ underflow concentration may require a paste thickener. If this is the case, the higher cost of a paste thickener will need to be balanced against the attractiveness of the high disposal concentration.

\subsection{Hydraulic issues - thickener underflow concentration $50 \% \mathrm{w} / \mathrm{w}$}

After dilution with the water present with the coarse rejects, the concentration of the fines reduces from the thickener under flow concentration of 50 to $47.5 \% \mathrm{w} / \mathrm{w}$. Based on the assumed rheology, the yield stress of the fines at $47.5 \% \mathrm{w} / \mathrm{w}$ concentration is $4.32 \mathrm{~Pa}$, and Equation 3 gives a transition velocity of $1.47 \mathrm{~m} / \mathrm{s}$, comfortably below the $2.08 \mathrm{~m} / \mathrm{s}$ velocity in the recycle pipeline and the $4 \mathrm{~m} / \mathrm{s}$ in the main pipeline. Hence, flow in both pipelines is turbulent as required.

For the assumed fines rheology (Equations 1 and 2), a thickener underflow concentration of 50\% w/w is about the maximum possible within the requirement to maintain turbulent flow in both the main and recycle pipelines.

\subsection{Pump power requirements - thickener underflow concentration $50 \% \mathrm{w} / \mathrm{w}$}

The predicted pressure gradient in the main pipeline is $1,132 \mathrm{kPa} / \mathrm{km}$ and in the recycle pipeline, the pressure gradient is $169 \mathrm{kPa} / \mathrm{km}$. The respective electrical operating powers are 581 and $39 \mathrm{~kW}$ giving a total operating electrical power per $\mathrm{km}$ of $620 \mathrm{~kW}$. This compares with the $870 \mathrm{~kW}$ required for the conventional system described in Section 2 and the $600 \mathrm{~kW}$ required for RFS with 40\% w/w thickener underflow concentration. A concrete type positive displacement pump could be an alternative to centrifugal pumps and may give a higher efficiency, but at the expense of a much higher capital cost. Centrifugal pumps are ideally suited to this turbulent flow application, unlike laminar flow paste pumping, where positive displacement pumps are required.

\section{$6 \quad$ Comparing RFS with high concentration laminar paste co- disposal}

The authors are not aware of any operating co-disposal paste pumping systems in the Australian coal industry. However, at least one co-disposal paste pumping system is believed to be being trialled in loop tests.

A paste pumping system would involve thickening the minus $2 \mathrm{~mm}$ fines to a paste consistency in a paste thickener, adding the coarse rejects and then pumping in laminar flow.

The minimum yield stress of the thickened fines required for a paste pumping system will be one that at least prevents settling of the coarsest particles under static conditions. Thomas (1977) provided the following equation for the yield stress required to support a sphere under static conditions.

$$
\tau y=\operatorname{kgd}\left(\rho_{p}-\rho_{v}\right)
$$

Where:

g $=$ gravitational constant. 
$\mathrm{d}=$ particle size in metres.

$\rho_{p}$ and $\rho_{v}=$ density of the particle and the vehicle slurry in $\mathrm{kg} / \mathrm{m}^{3}$.

Thomas gave $\mathrm{k}=0.092$, and a number of authors have given a similar value. For present purposes, $\mathrm{k}$ is assumed 0.1 . For $50 \mathrm{~mm}$ top size rejects of density $2,200 \mathrm{~kg} / \mathrm{m}^{3}$ in, say, a fines vehicle slurry of density $1,350 \mathrm{~kg} / \mathrm{m}^{3}$, Equation 4 gives a minimum yield stress to prevent settling of $42 \mathrm{~Pa}$.

If it is assumed that a fines yield stress of $42 \mathrm{~Pa}$ is sufficient, this equates to a fines concentration of $61.4 \%$ $\mathrm{w} / \mathrm{w}$. After allowing for the dilution water present with the coarse rejects, the paste thickener underflow concentration before rejects addition is required to be $65.2 \% \mathrm{w} / \mathrm{w}$ with a yield stress of $85 \mathrm{~Pa}$. The resulting volume concentration of coarse rejects in the mixture is $47 \%$. Total concentration delivered to disposal is $84.1 \% \mathrm{w} / \mathrm{w}$.

The above assumes that the minimum yield stress required for static stability is sufficient to produce a stable, pumpable slurry when the rejects are added. Thomas (1979) determined that, in general, the yield stress given by Equation 3 is not sufficient to prevent settling once the slurry is sheared by the flowing stream. Hence, any paste pumping system is likely to require a higher fines yield stress, perhaps $100 \mathrm{~Pa}$. For the particular fines considered here, the yield stress given by Equation 1 indicates a fines concentration of $66.7 \% \mathrm{w} / \mathrm{w}$ is required to give a yield stress of $100 \mathrm{~Pa}$. After allowing for the dilution water with the coarse rejects, the paste thickener underflow concentration before rejects addition is required to be $71.8 \% \mathrm{w} / \mathrm{w}$ with a yield stress of $230 \mathrm{~Pa}$. The resulting volume concentration of coarse rejects in the mixture is $50 \%$. The $50 \%$ volume concentration is approaching maximum packing concentration, and the pipeline may be prone to blockage problems. For example, it is noted that the volume concentration of coarse $2.5-10 \mathrm{~mm}$ aggregate in concrete is typically only around $30 \%$ (Jolin et al. 2009). The $30 \%$ volume concentration is significantly lower than the $50 \%$ volume concentration of the coarse rejects in the paste slurry. Nevertheless, if pumping the resulting laminar paste flow mix proves feasible, then the total weight concentration delivered to disposal is $87 \% \mathrm{w} / \mathrm{w}$. Pressure gradients are expected to be high, perhaps around $2,000 \mathrm{kPa} / \mathrm{km}$.

\section{$7 \quad$ Disposal site advantages}

The typical arrangement for a combined reject and tailings emplacement formed using a conventional pumped co-disposal system consists of a series of strips as illustrated in Figure 5. 


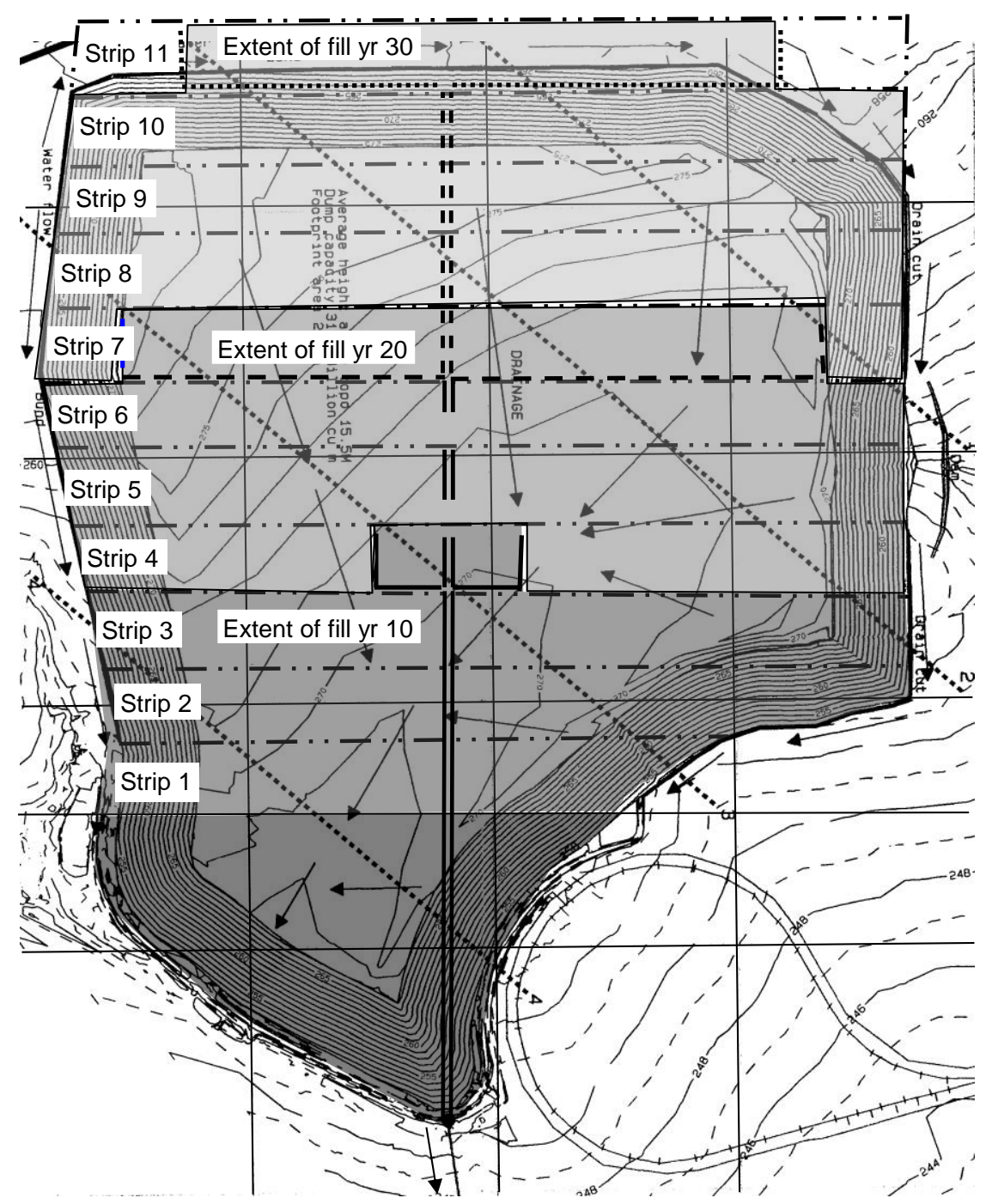

\section{Figure 5 Conventional co-disposal emplacement}

Each strip is usually divided into a number of cells, and each is initially constructed with a wall height of, say, $3 \mathrm{~m}$. The dimension of each cell, in this case, is $150 \mathrm{~m}$ wide, corresponding to the width of a strip, and $150 \mathrm{~m}$ long, and is constructed of reject material, the crest of the wall being wide enough for a scraper. The cells are constructed and filled from the centre line of the deposit where the pipelines are located. Cells are filled by progressively moving one or two pipe discharge cannons around the periphery of each cell in order to progressively cover the fine tailings that bleed from the deposition point and the ensuing beach, thus preventing a tailings dam from developing. Water that is released from the deposit is collected in adjacent empty cells via decant pipes placed in the cell walls where it progressively clarifies before being pumped to the process water dam for re-use. Once the initial cell structure is full, the cannons are progressively moved and arranged so as to build the cell to its full height (in this case, some $15 \mathrm{~m}$ ). The adjacent cell in the strip is then filled in a similar manner by extending the pipework laterally across the emplacement until the edge is reached.

The process of building cells, moving cannons, extending and moving pipework, managing the construction of the emplacement and moving and contouring the deposited combined reject and tailings requires the constant input of labour and various items of equipment. This particular aspect of the management of the emplacement comprises a major component of the overall operating cost. 


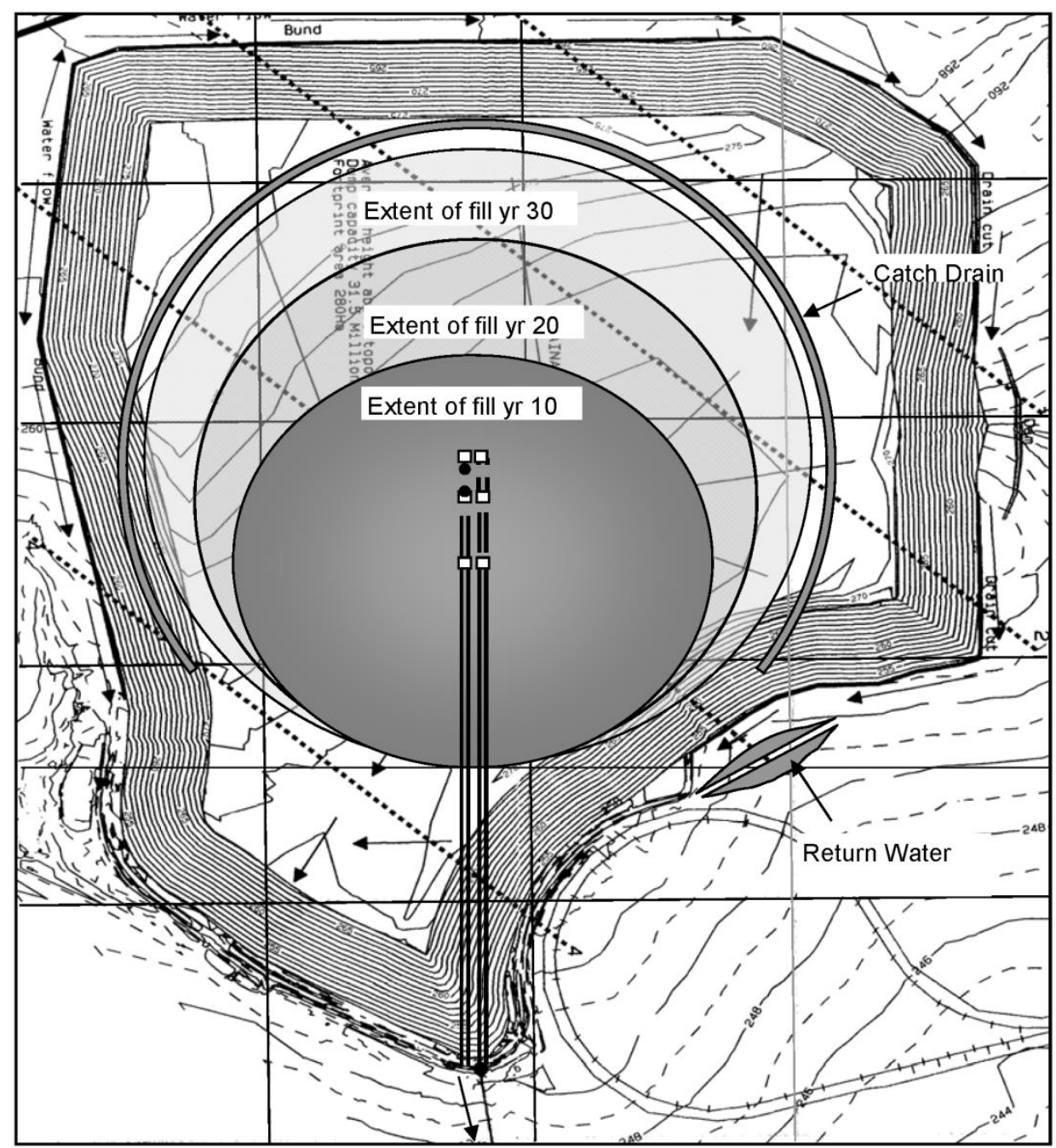

\section{Figure 6 RFS single point cone deposit}

By comparison, the arrangement of a combined reject and tailings emplacement constructed by employing an RFS system can take the form of a single cone with a postulated slope of approximately 1 in 8 , as illustrated in Figure 6. The actual slope of the cone is expected to be in the range from 1 in 5 to 1 in 10 . The steeper end of this range is achieved on the upper part of an immature conventional low solids concentration pumped co-disposal beach, while the flatter end of this range represents a more mature conventional co-disposal beach slope (Morris \& Williams 1997). While the actual slope will depend on the actual conditions applying at the time, a precedent exists in natural alluvial fans that also form at about 1 in 8. The actual inclination and shape of the slope formed by an RFS system is the subject of future testwork.

The pumping of combined rejects and tailings at high solids concentrations using RFS will greatly reduce the washing-out of fines that occurs at the low solids concentrations and high discharge velocities associated with conventional co-disposal. For example, the discharge flow rates in Figures 3 and 4 are respectively 438 and $371 \mathrm{~m}^{3} / \mathrm{h}$, less than half the typical $944 \mathrm{~m}^{3} / \mathrm{h}$ discharge from a conventional co-disposal system. This will promote a more uniformly steep beach slope, as will the significant rheology of the fines. The $4.3 \mathrm{~Pa}$ yield stress and $11 \mathrm{mPas}$ plastic viscosity relevant to Figure 4 will entrain the finer fractions of the coarse refuse. The resulting mixture of thickener underflow and entrained reject fines will have an even higher yield stress and plastic viscosity, thereby helping to maintain much more homogeneity within the deposit than for conventional co-disposal pumped in essentially dirty water. 
Figures 5 and 6 show a comparison of the relative size and arrangement of emplacements formed using a conventional combined rejects and tailings emplacement, one formed by conventional co-disposal techniques and one formed as a single cone using RFS. Figure 6 shows a superimposed view of the extent of the emplacements formed by either method after 30 years of operation, the conventional emplacement is $15 \mathrm{~m}$ above ground level, while the highest point of the conical emplacement is $80 \mathrm{~m}$ above ground level. Not surprisingly, the single conical deposit occupies less plan view area. It may be seen that the most economical arrangement for an emplacement constructed using the RFS system is a single cone. However, it is possible that where there is, say, a limit on the height of the emplacement, to construct an emplacement that takes the shape of a long pile with a triangular cross section. This being done by moving the deposition point more rapidly in the desired direction once the maximum height of the initial cone has been reached, the higher the elevation, the less frequent the necessity of moving the discharge point is. This provides a deal of flexibility in forming the overall plan view dimensions and shape of an emplacement formed using the RFS system. Once at the desired elevation, the discharge point can be moved in a locus that is not necessarily a straight line, thus forming emplacements that are of almost any desired form, which are more similar to those that occur as a consequence of natural processes.

This form of emplacement is made possible by the high solids concentration of the deposited combined reject and tailings afforded by RFS, where there is little excess liquid and velocity of flow to cause the washing-out of fines from the deposited mixture. By comparison, with conventional low solids, highvelocity pumped co-disposal of combined rejects and tailings, the wash-out of fines is substantial, being up to $80 \%$ in the upper layer of deposition (Morris \& Williams 1997). The advantages of an emplacement formed by RFS are noted below:

- Reduced requirement for earthworks, a low catch drain being all that is required.

- Reduced length of pipework required as a consequence of not having to reach the edges of the deposit.

- No movement of pipe required, just additional length as the cone grows.

- Minimal management required of the construction of the emplacement.

- Once the initial cone has reached a reasonable height (say, after three years), the frequency of the movement of the discharge point is reduced to fewer than five, progressively reducing as the height of the cone grows.

- Reduced pumping distance, pumping power and number of installed pumps.

- Greatly reduced input of labour and equipment to manage the emplacement.

\section{Cost comparison}

The conventional co-disposal system involves two high-cost, thick-walled pipelines and a total of four gravel pumps (two per pipeline), together with a return water pipeline. In contrast, the equivalent RFS system involves only one high-cost, thick-walled pipeline and two gravel pumps together with a recycle pipeline. The cost savings associated with one thick-walled pipeline and two gravel pumps more than offset the cost of the RFS recovery unit.

Discharging from a single point offers significant economic cost benefits over the current co-disposal alternative. A detailed study involving both capital and operating costs of the RFS technology versus current co-disposal methodology for a mine life of 29 years determined a total accumulated cost saving of 51\% on current co-disposal methods. Significantly, the operating cost benefit component of the RFS alternate was $49 \%$ when compared to operating a conventional co-disposal system. 


\section{$9 \quad$ Discussion and conclusions}

Pumped co-disposal of minus $50 \mathrm{~mm}$ coarse rejects with thickener underflow fines is practised at a number of Queensland coal mines. However, because of the typical 70:30 ratio of coarse rejects to fines, large quantities of dilution water must be added to reduce the volume concentration of the coarse rejects to an acceptable level to obtain reliable operation. The total solids concentration delivered to the disposal site is typically around $20 \% \mathrm{w} / \mathrm{w}$. The fines concentration is so low that the coarse rejects are essentially pumped in dirty water. As a result, at the disposal site, the fines are not trapped in the rejects but tend to filter through and form a dam at the toe of the deposit. Some water is lost through evaporation, and the remainder must be pumped back to the plant. A considerable amount of effort is required to relocate the two rejects and diluted fines discharge points, as well as for the remixing of the rejects and fines using bulldozers.

The RFS system negates the need for adding dilution water and achieves the desired reduction in coarse rejects volume concentration by recycling some of the fines. Typically, the total concentration of the co-disposal mixture delivered to the disposal site is in the range $67.5-75 \% \mathrm{w} / \mathrm{w}$. Upon disposal, this mixture remains essentially homogeneous and suitable for single point discharge to form a disposal cone and requires lifting of the single discharge point with only minor extension. No additional earthmoving activity is required on the deposit. Operating power requirements are about three quarters of that required for conventional co-disposal and capital cost of pumps about half. Because the coarse rejects are transported in a high density, viscous 'vehicle' slurry, pipe wear is expected to be considerably less than with the conventional co-disposal pumping systems.

RFS system performance has been compared with a laminar flow paste co-disposal pumping system; although, to the authors' knowledge, there are no operating paste co-disposal systems at present. However, some loop trials are believed to be being conducted. The results of these trials will need to be assessed, but the authors foresee some potential for blockage problems with paste co-disposal because of the 70:30 ratio of coarse rejects to fines. The authors believe that the reliability of the turbulent flow operation of RFS is preferred. Even if operability issues are overcome with the laminar flow paste system, the total concentrations delivered to disposal are not much higher than if delivered by RFS.

\section{References}

Jolin, M, Burns, D, Bissonnette, B, Gagnon, F \& Bolduc, L-S 2009, 'Understanding the pumpability of concrete', in F Amberg \& KF Garshol (eds), Proceedings of Shotcrete for Underground Support XI, Engineering Conferences International, New York, viewed 9 February 2015, http://dc.engconfintl.org/shotcrete/17

Miura, H \& Mase, S 1979, 'Operation and maintenance of slurry transportation system at hydraulic coal mine', in D Lambert (ed.), Proceedings of the 4th International Technical Conference on Slurry Transportation, Slurry Transport Association, Washington DC, pp. 43-50.

Morris, PH \& Williams, DJ 1997, 'Results of field trials of co-disposal of coarse and fine coal wastes', Transactions of the Institution of Mining and Metallurgy, vol. 106, pp. A38-A41.

Paterson, AC \& Watson, N 1979, 'The NCB pilot plant for solids pumping at Horden Colliery', in HS Stephens \& L Gittins (eds), Proceedings of the Hydrotransport 6 conference, British Hydromechanics Research Association, Cranfield, pp. 353-366.

Prettlin, W \& Gaessler, H 1976, 'Bases of calculation and planning for the hydraulic transport of run-of-mine coal in pipelines

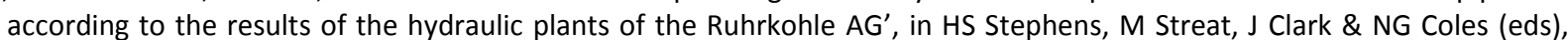
Proceedings of the Hydrotransport 4 Conference, British Hydromechanics Research Association, Cranfield, pp. E213-E236.

Siebert, H, Kortenbusch, W \& Harzer, H 1980, 'Further experience with horizontal and vertical hoisting of coarse run of mine coal at Hansa hydromine', in HS Stephens \& L Gittins (eds), Proceedings of the Hydrotransport 7 Conference, British Hydromechanics Research Association, Cranfield, pp. 41-54.

Thomas, AD 1977, 'A rational design philosophy for long distance slurry pipelines', Chemical Engineering in Australia, pp. 22-33.

Thomas, AD 1979, 'Pipelining of coarse coal as a stabilized slurry - another viewpoint', in D Lambert (ed.), Proceedings of the 4th International Technical Conference on Slurry Transportation, Slurry Transport Association, Washington DC, pp. 196-205.

Wilson, KC \& Thomas, AD 2006, 'Analytic model of laminar-turbulent transition for Bingham plastics', The Canadian Journal of Chemical Engineering, vol. 84, no. 5, pp. 520-526. 